\title{
An overview of peanut and its wild relatives
}

\author{
David J. Bertioli ${ }^{1,2 *}$, Guillermo Seijo ${ }^{3}$, Fabio O. Freitas ${ }^{4}$, José F. M. Valls ${ }^{4}$, \\ Soraya C. M. Leal-Bertioli ${ }^{4}$ and Marcio C. Moretzsohn ${ }^{4}$ \\ ${ }^{1}$ University of Brasília, Institute of Biological Sciences, Campus Darcy Ribeiro, Brasília-DF, \\ Brazil, ${ }^{2}$ Catholic University of Brasília, Biotechnology and Genomic Sciences, Brasília-DF, \\ Brazil, ${ }^{3}$ Laboratorio de Citogenética y Evolución, Instituto de Botánica del Nordeste, \\ Corrientes, Argentina and ${ }^{4}$ Embrapa Genetic Resources and Biotechnology, PqEB Final \\ W3 Norte, Brasília-DF, Brazil
}

\begin{abstract}
The legume Arachis hypogaea, commonly known as peanut or groundnut, is a very important food crop throughout the tropics and sub-tropics. The genus is endemic to South America being mostly associated with the savannah-like Cerrado. All species in the genus are unusual among legumes in that they produce their fruit below the ground. This profoundly influences their biology and natural distributions. The species occur in diverse habitats including grasslands, open patches of forest and even in temporarily flooded areas. Based on a number of criteria, including morphology and sexual compatibilities, the 80 described species are arranged in nine infrageneric taxonomic sections. While most wild species are diploid, cultivated peanut is a tetraploid. It is of recent origin and has an AABB-type genome. The most probable ancestral species are Arachis duranensis and Arachis ipaënsis, which contributed the A and B genome components, respectively. Although cultivated peanut is tetraploid, genetically it behaves as a diploid, the A and B chromosomes only rarely pairing during meiosis. Although morphologically variable, cultivated peanut has a very narrow genetic base. For some traits, such as disease and pest resistance, this has been a fundamental limitation to crop improvement using only cultivated germplasm. Transfer of some wild resistance genes to cultivated peanut has been achieved, for instance, the gene for resistance to root-knot nematode. However, a wider use of wild species in breeding has been hampered by ploidy and sexual incompatibility barriers, by linkage drag, and historically, by a lack of the tools needed to conveniently confirm hybrid identities and track introgressed chromosomal segments. In recent years, improved knowledge of species relationships has been gained by more detailed cytogenetic studies and molecular phylogenies. This knowledge, together with new tools for genetic and genomic analysis, will help in the more efficient use of peanut's genetic resources in crop improvement.
\end{abstract}

Keywords: Arachis; breeding; crop improvement; genetic resources; groundnut; peanut; wild species

\section{Introduction Peanut's importance in the world, and some peculiarities of its biology}

Peanut, also commonly known as groundnut (Arachis bypogaea), is a major food crop, grown throughout the tropics and sub-tropics. World annual production is

*Corresponding author. E-mail: david.bertioli@pq.cnpq.br about 38 million tonnes. Like so many other crops, it has become most important in regions of the world far from its original home. Peanut is particularly important in Asia, which accounts for $64 \%$ of the world production, and where it provides a similar number of calories to soya. In Africa, which accounts for $26 \%$ of the world production, peanut has a key role as providing protein, energy and iron; amazingly, on this continent, its production exceeds that of all other grain legumes put together. In the USA, largely due to the research efforts 
of Dr George Washington Carver, peanut became an important crop in the South. The USA now accounts for some $6 \%$ of the world production. South America currently produces only $3 \%$ of the world production, but it is there that the genus Arachis is endemic, and cultivated peanut originally arose (production Statistics from 2008 (FAOSTAT, 2008)).

The first written reference to peanut seems to have been published in 1535 by Gonzalo Hernández de Oviedo y Valdés in his chronicles of his travels in the Americas. He wrote that maní (peanut) 'is very common with the Indians', and, in words that ooze the historical context of colonization, that 'Christians take little comfort in them, being eaten mostly by lowly men and boys and slaves and by people who do not pardon their taste for anything'. Over 200 years later, peanut was given its scientific name by Linnaeus, in his Species Plantarum of 1753. It was the first of its genus described, and thus became the genus' type species. The species epithet bypogaea refers to the character that perhaps mostly calls attention to this remarkable plant. It is geocarpic, that is, its fruits develop below the ground. Geocarpy is rare among flowering plants, but it is important to note that it is not unique. It is present in a wide array of species, from monocots (Meney et al., 1990) to other legumes (e.g. subterranean clover Trifolium subterraneum L. and bambara groundnut Voandzeia subterranean L.). However, these genera and species are phylogenetically scattered, and geocarpy seems to have developed many times by convergent evolution, in some cases, apparently in response to arid environments (Barker, 2005). Accordingly, it is an adaptation to heat and drought that are key to peanut's success as a crop plant in many regions of its cultivation.

The flowers of Arachis species appear superficially similar to other Papilionoid legumes; however, there are intriguing differences that relate to geocarpy. The ovary is not enclosed by the petals, but is at the base of what appears to be the flower stalk. In fact, this 'stalk' is a hollow structure named a hypanthium, through which runs the style. The hypanthium is typically $1-2 \mathrm{~cm}$ long, but in some species may be up to $15 \mathrm{~cm}$. After fertilization, the embryo undergoes only a very few cell divisions and then becomes quiescent. Then, the intercalary meristem of the ovary begins to elongate forming a 'peg' structure with the ovary just behind the lignified tip. This peg grows downwards and penetrates the soil, where embryo development resumes and the pod is formed (Smith, 1950). In A. hypogaea, the pods develop only a centimetre or two below the soil surface, but in wild species, they develop much further down. In A. hypogaea, the seeds in the pods develop side by side in much the same way as pea seeds. However, in wild species, the development of an intercalary meristem between the (typically two) seeds draws out the pod between the seeds into a long thread-like isthmus. This creates a space between the seeds and, when they germinate, the competition between the seedlings is reduced (Krapovickas and Gregory, 1994).

\section{The position of the genus Arachis within the legumes}

The legume family (Fabaceae or Leguminosae) is divided into three very large subfamilies, Mimosoideae, Caesalpinioideae and Papilionoideae. Almost all economically important legumes fall within two sub-clades of the Papilionoideae that diverged from each other some $50 \mathrm{Myr}$ ago, the Phaseoloids and Galegoids (Fig. 1; Wojciechowski et al., 2004; Lewis et al., 2005).

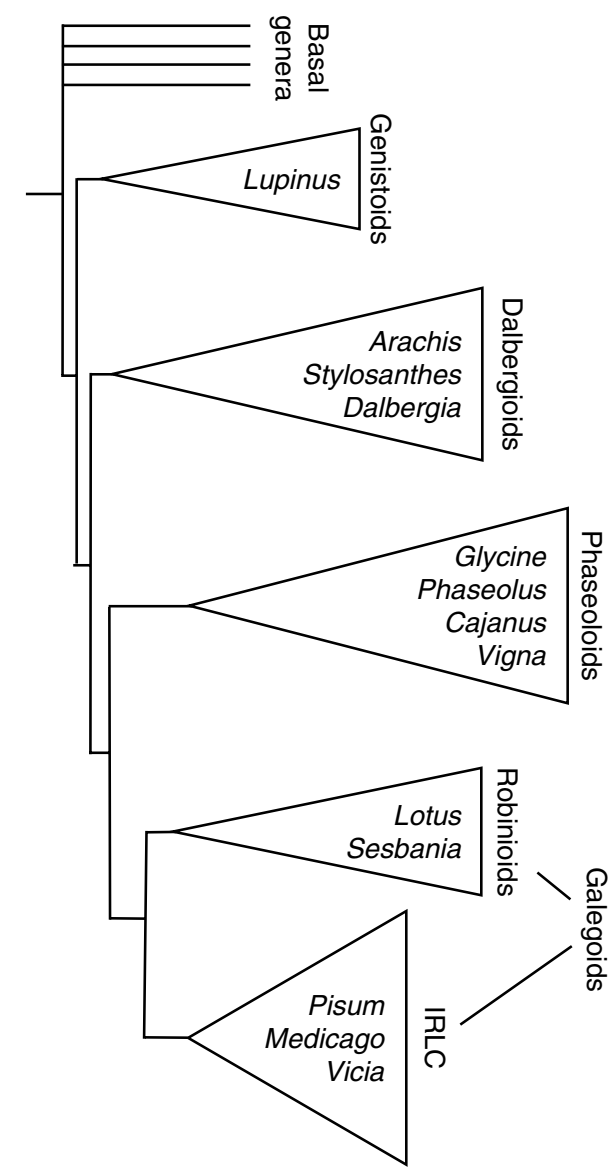

Fig. 1. A tree representation of the phylogeny of the Papilionoids with triangles representing the major clades, and the two subclades of the Galegoids; the Robinioids and the IRLC (plastid DNA inverted repeat lacking clade). Names of some notable genera are placed within the triangles. Note that Arachis, which is a member of the Dalbergioids, represents a more basally diverged clade than the Phaseoloid or Galegoid legumes. The figure is from Bertioli et al. (2009) and is a simplified and stylized phylogeny based on a tree in Wojciechowski et al. (2004). 
The Phaseoloids, also known as the 'warm season', 'tropical' or 'millettioid' clade, is a pan-tropical group with a base chromosome number of $1 n=11$ or 12 . This clade includes bean (Phaseolus vulgaris), cowpea (Vigna unguiculata), soya (Glycine max) and pigeon pea (Cajanus cajan).

The Galegoids, also known as the 'cool season', 'temperate' or 'Hologalegina' clade, include over 4800 species with their centre of distribution in Europe and the Mediterranean and make up the vast majority of legumes distributed in temperate regions of the world. This clade includes clover (Trifolium ssp.), pea (Pisum sativum), lentil (Lens culinaris), field bean (Vicia faba), chickpea (Cicer arietinum) and alfalfa (Medicago sativa).

However, Arachis falls in a different Papilionoid clade, the Dalbergioids. This clade is more basal in its divergence than the phaseoloids and galegoids (Fig. 1). The Dalbergioids are predominantly New World and tropical and have an ancestral chromosome number of $1 n=10$. All species of Arachis are geocarpic, but none of the species in its sister genus Stylosanthes have this trait. In this way, geocarpy taxonomically clearly defines the genus Arachis. Also, most unusually among flowering plant genera, the most significant characters that separate the species of the genus are not above ground, but below, the fruits, rhizomatous stems, root systems and hypocotyls (Krapovickas and Gregory, 1994).

Because of geocarpy, an individual plant within the genus Arachis can usually disperse its seed only about $1 \mathrm{~m} /$ year. Plausible agents of distribution over longer distances are water and in some special cases, humans. The species also show a predominance of autogamous and asexual reproduction, and a steady evolutionary drift that leads to noticeable incompatibilities between different collections of the same species. These factors are fundamental to the biology and taxonomy of the genus, and make it more complex than most.

By mid-20th century, some 10-15 species had been described, but among these, there were numerous confusions. At this point began the work of a group of researchers based within the Americas, who with systemic collections, extensive experimental crosses, morphological observations and cytogenetics would produce the first broad treatment of the genus. Their landmark monograph recognized 69 species, it was published in Spanish, and recently has been translated into English (Table 1; Krapovickas and Gregory, 1994; Krapovickas and Gregory, 2007). Subsequently, 11 new species have been described (Table 1; Valls and Simpson, 2005), also around ten more have been collected in the last decade but still have to be formally described.
Table 1. Described sections and species of the genus Arachis part 1 (synonyms not listed)

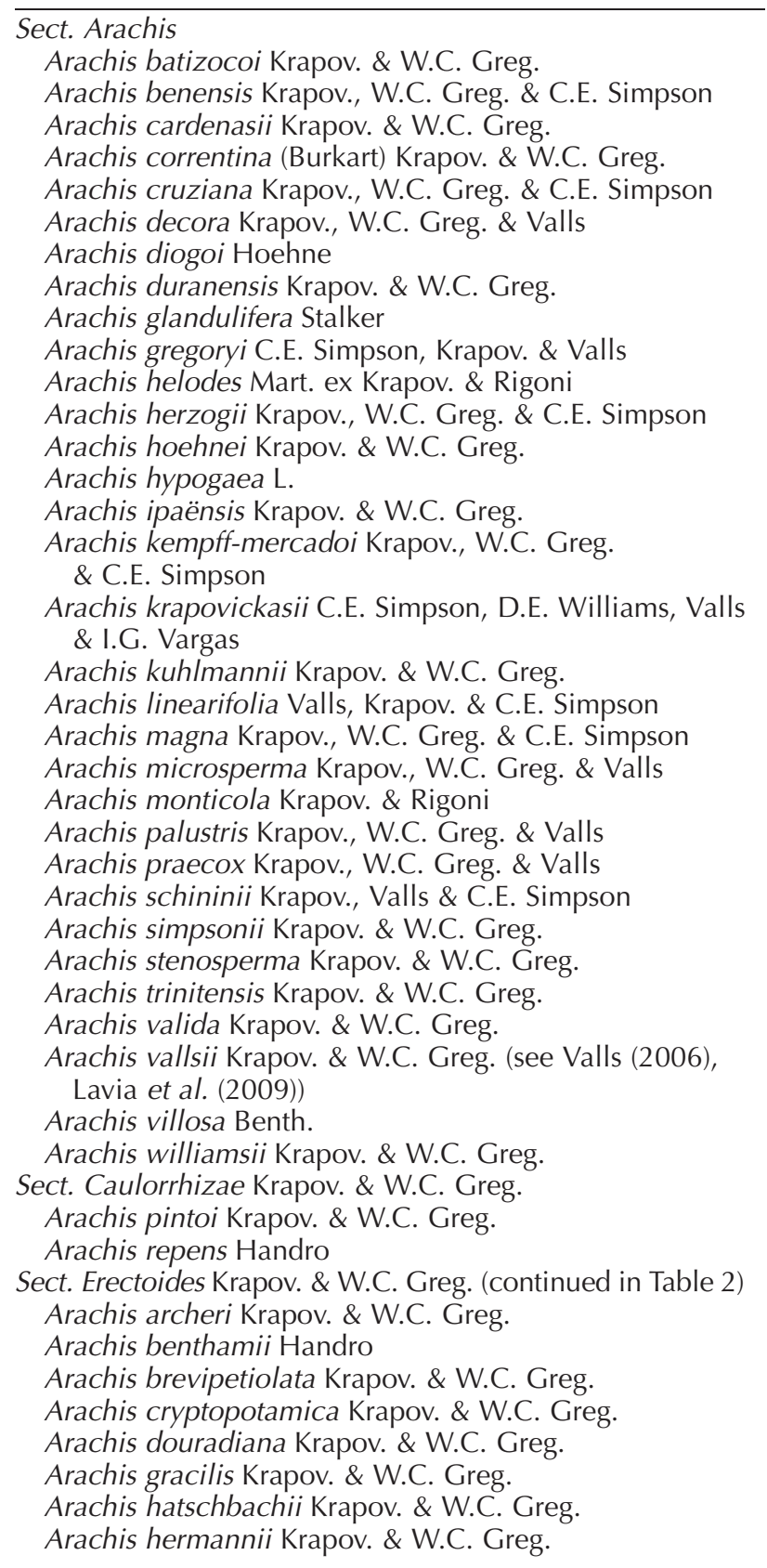

Based on: Krapovickas and Gregory (1994), Valls and Simpson (2005), and Lavia (2009).

\section{The distribution and ecology of the genus}

The genus is distributed within a large region of South America, which extends from the eastern foothills of the Andes Mountains in Bolivia and northern Argentina to the Atlantic coast in Brazil and from the southern limit of the Amazonian rainforest towards the northern 
Table 2. Described sections and species of the genus Arachis part 2 (synonyms not listed)

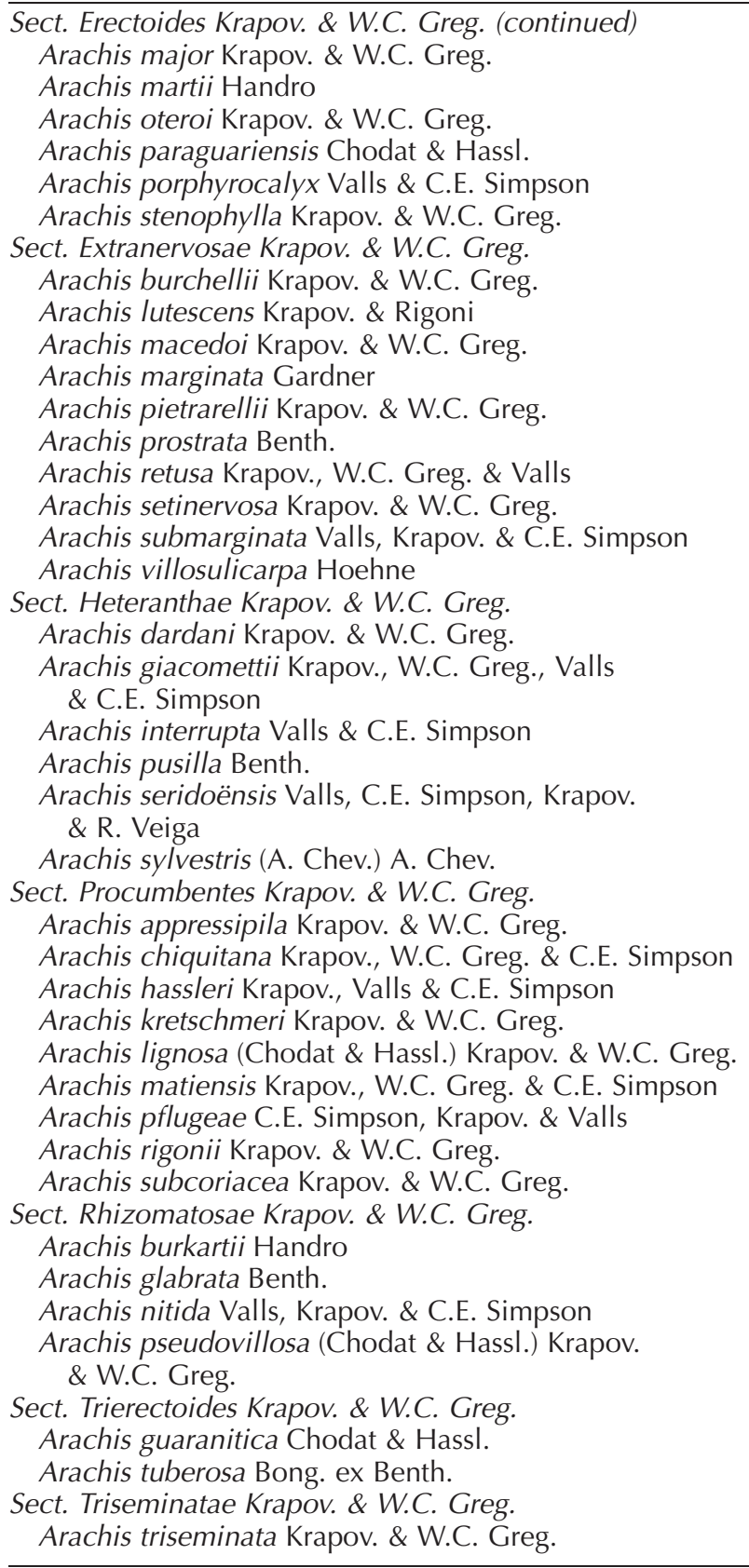

Based on: Krapovickas and Gregory (1994), Valls and Simpson (2005), and Lavia (2009).

coast of La Plata River in Uruguay (Fig. 2; Krapovickas and Gregory, 1994). Within this area, the species may either have extended ranges or be limited to only one collection site. The distribution areas of the species may overlap, but sympatric populations are rarely observed. Some of the species are composed of populations scattered throughout the entire species range, but others occur in a few small populations often separated by long distances. Reflecting the geocarpic habit, each population usually has tens to hundreds of individuals, arranged in patches of different sizes or with a more or less regular distribution.

Arachis species are adapted to a wide variety of habitats. They can be found in the xerophytic forests, in temporarily flooded areas, in grasslands and in open patches of the sub-tropical rainforest. Soil preferences are diverse ranging from rock outcrops, layers of laterite pebble, heavy soils, poorly drained areas to well drained sandy soils. They grow spontaneously from sea level on the Atlantic coast in Brazil and Uruguay to around $1450 \mathrm{~m}$ in the Andes Mountains of Northwestern Argentina. In spite of the ample range of ecological preferences displayed by the wild species, the genus as a whole is mainly associated with the savannah-like Cerrado biogeographical region as defined by Cabrera and Willink (1973).

According to the distribution of ancestral characters, it has been proposed that the genus originally evolved in an area that divides the Parana and Paraguay River basins in Mato Grosso do Sul State (Brazil) and northern Paraguay (Krapovickas and Gregory (1994)). However, the major centre of morphological, cytogenetic and genetic variation for the genus is around the Brazilian and Bolivian pantanal (Gregory et al., 1980; Fernández and Krapovickas, 1994; Lavia, 1999).

\section{The infrageneric taxonomy of Arachis}

Based on morphology, cross-compatibility, viability of the hybrids, geographic distribution and cytogenetics, the Arachis species have been arranged in nine taxonomic sections: Trierectoides, Erectoides, Procumbentes, Rhizomatosae, Heteranthae, Caulorrbizae, Extranervosae, Triseminatae and Arachis (Krapovickas and Gregory, 1994; Fernández and Krapovickas, 1994; Lavia, 1999; Valls and Simpson, 2005). Among these, the section Trierectoides is considered to have the most ancestral characters, such as tuberous hypocotyls or roots, trifoliated leaves and vaginated stipules, the last two of these characters resembling those present in the genus Stylosanthes. On the other hand, the section Arachis is considered to be the most diverse and derived, harbouring both annual and perennial species and different chromosome numbers, ploidy levels and karyotype structures. Between these two sections, species that belong to sections Erectoides and Procumbentes seem to be the most related to those within the section Arachis. Some of the members of sections Rhizomatosae, Heteranthae and Caulorrbizae may produce hybrids with the most derived sections, but others show a strong genetic isolation. Sections Extranervosae 
and Triseminatae are the most isolated sections, and their evolutionary position has to be determined (Krapovickas and Gregory, 1994). Recent phylogenies of rDNA sequences that use Stylosanthes as outgroups generally support the grouping of the species within the sections, but do not support Trierectoides as the most primitive. They suggest that sections Extranervosae, Heteranthae and Triseminatae are most primitive, section Arachis

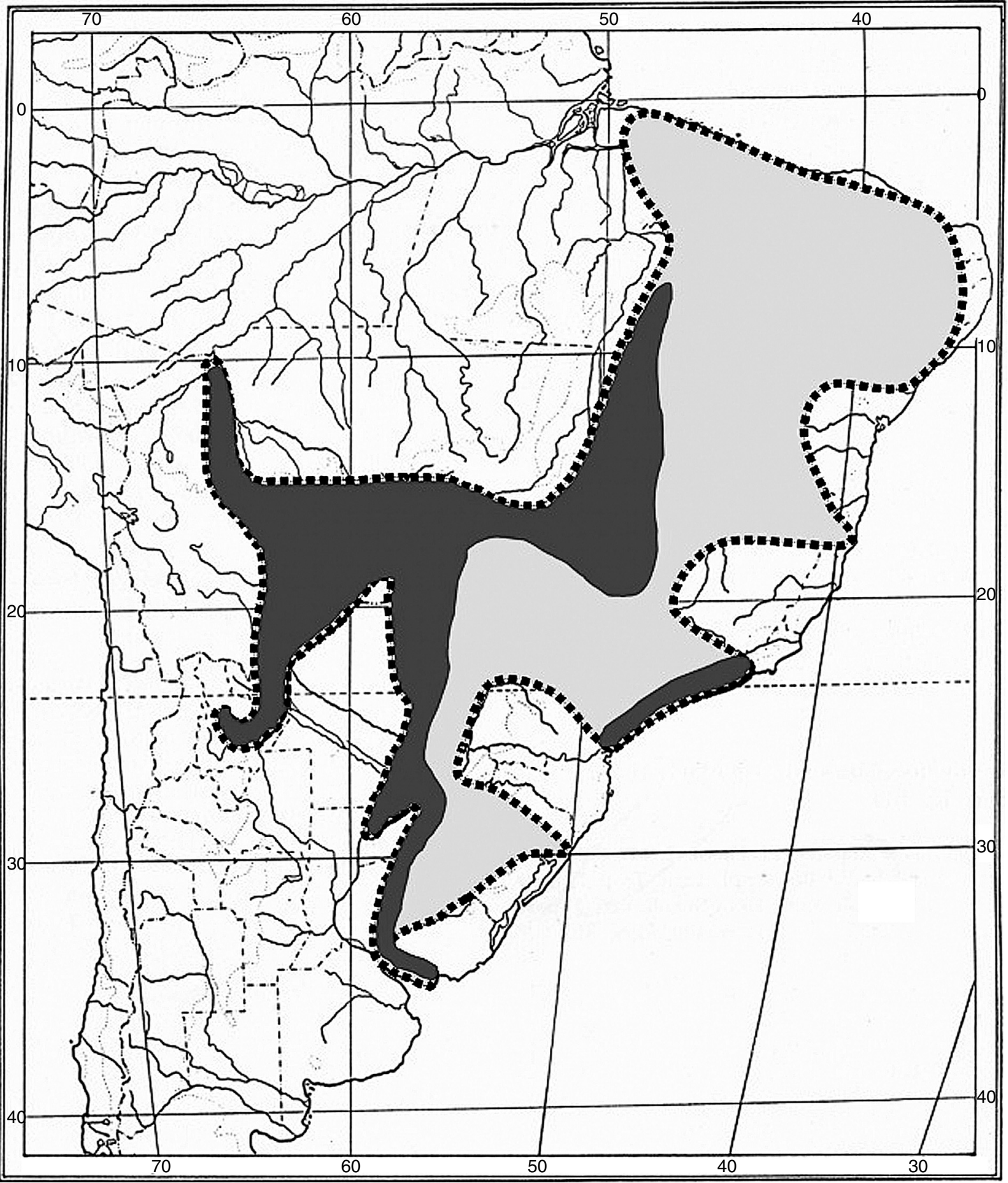

Fig. 2. Geographic distribution of all the species in the genus Arachis (delimitated by dashed line) and the distribution of the species in the section Arachis (delimitated by darker grey area). The discontinuous section Arachis area on the coast of Brazil is of Arachis stenosperma. This distribution is almost certainly not natural. This species was cultivated for food by native peoples, and it is believed that plants in this region are descendants of plants that persisted and spread in the wild after escaping from cultivation. 
is the most derived, and that sections Caulorrbizae, Erectoides, Procumbentes, Rhizomatosae and Trierectoides are intermediate in position (Wang et al., 2010; Bechara et al., 2010).

\section{The species relationships within the botanical section Arachis, and the most probable ancestors of cultivated peanut}

Among the nine different sections, the type section Arachis has received particular attention because it contains the cultivated peanut and its putative wild progenitors. In accordance with its status as the most evolutionarily derived section, geographically it is the most widely distributed (Fig. 2). It extends in an east-west direction between the Chapada dos Parecis in the central west of Mato Grosso State (Brazil) and the northern edge of the Chacoan region. From this latitudinal central axis, in the east, the species extend towards the northeast along the Tocantins River (central Brazil) and southward along the Paraguay-Paraná and Uruguay River Basins (Paraguay, Argentina and Uruguay) reaching the northern shore of La Plata River. In the west, they are found towards the northwest along the Mamoré and Guaporé Rivers in north Bolivia and towards the southwest along the Parapetí, Pilcomayo, Bermejo, San Francisco and Juramento River Basins in southern Bolivia and northern Argentina. In its centre, the section Arachis overlaps with sections Procumbentes, Erectoides and Trierectoides, towards the southeast with section Rhizomatosae, and from the centre towards the northwest with section Extranervosae. It has parapatric distribution with sections Caulorrbizae and Heteranthae at the northwest edge of its distribution. Section Triseminatae is the only one with a completely separate distribution from the Arachis section area (Krapovickas and Gregory, 1994).

The chromosomes of the section Arachis species are small and mostly metacentric. In spite of this, analyses of karyotypes do provide valuable information. Diploid species with $2 n=20$ have been assigned to three different genomes, A, B and D. The species with the A genome are characterized by a small pair of chromosomes with allocyclic condensation, 'the A chromosomes' after Husted (1936) (Smartt et al., 1978). The remaining species with symmetric karyotypes but without A chromosomes have been considered members of the B genome (Smartt et al., 1978; Smartt and Stalker, 1982; but also see later in manuscript). The only species with an asymmetric karyotype (Arachis glandulifera) is classified as having the D genome (Stalker, 1991). Diploid species with $2 n=18$ are not well characterized, and their genome constitution still has to be determined (Lavia, 1996, 1998; Peñaloza and Valls, 1997). Cultivated peanut and the wild Arachis monticola are allopolyploid species $(2 n=40)$ and have an AABB genome constitution (Husted, 1936; Smartt et al., 1978; Fernández and Krapovickas, 1994). Analysis using molecular markers corroborates the division of the section into two main groups consisting of the $\mathrm{A}$ and $\mathrm{B}$ genomes, with the $\mathrm{D}$ genome and the three $2 n=18$ species being closely related to the $\mathrm{B}$ genome species (Halward et al., 1992; Moretzsohn et al., 2004; Milla et al., 2005; Tallury et al., 2005; Bravo et al., 2006; Gimenes et al., 2007; Cunha et al., 2008; Tang et al., 2008). Further supporting these main divisions within the sections, for diploids, there is a remarkable correlation between the presence of A chromosomes and perennial growth habit. All A genome species are perennials, except Arachis duranensis and Arachis schininii. Indeed, it has been commented that without the tetraploid AABB genomes to unify them, the A and B genome species could have been placed into two distinct sections.

Because the A and B genomes are closely related to the genomic components of cultivated peanut, the fine structure of the relationships of the species with these genomes is worth considering more closely.

For the A genome species, three different karyotype subgroups could be established on the basis of the number of rDNA loci and chromosomes with centromeric heterochromatin (Robledo et al., 2009). Within this scheme, the A genome of $A$. hypogaea falls into the same subgroup as A. duranensis, Arachis villosa, A. schininii and Arachis correntina. Concerning molecular studies, the placement of diploid and tetraploid species in the same study is problematic, because the latter should occupy not one, but two, positions within a tree of relationships. In spite of this, A. hypogaea often falls closely to $A$. duranensis, which, in turn, is most closely associated with A. villosa, Arachis stenosperma and Arachis diogoi (Moretzsohn et al., 2004; Milla et al., 2005; Bravo et al., 2006; Cunha et al., 2008; Tang et al., 2008; Koppolu et al., 2010).

The species included within the $\mathrm{B}$ genome are more diverse in their karyotype formulas (Fernández and Krapovickas, 1994) and karyotype structure (Seijo et al., 2004). The analysis of heterochromatin distribution and rDNA loci mapping by FISH demonstrated that these species can be arranged into three different groups. Species included in each group have a strong genetic isolation with those included in the other groups. On this basis, the B genome sensu lato or, as they may be better termed the 'non-A genome' taxa, were segregated into three different genomes: B sensu stricto, F and K (Seijo et al., 2004; Robledo and Seijo, 2010). The B genome s.s. is deprived of centromeric 
heterochromatin and consists of the B component of $A$. hypogaea, Arachis ipaënsis, Arachis magna, Arachis gregoryi, Arachis valida, and Arachis williamsii. The other two genomes have centromeric bands on most of the chromosomes, but differ in the amount and distribution of heterochromatin. The molecular data provide strong support for the division of the $\mathrm{B}$ genome s.s. from the other non-A genomes. Often, $A$. hypogaea is associated with $A$. ipaënsis, but also to A. magna, A. williamsii, A. gregoryi and A. valida (Moretzsohn et al., 2004; Milla et al., 2005; Tallury et al., 2005; Bravo et al., 2006). The other group usually contains Arachis batizocoi, Arachis benensis and Arachis cruziana. The only study that included Arachis krapovickasii grouped it to these later three species (Moretzsohn et al., 2004).

The exact genetic origin of cultivated peanut has long interested plant taxonomists, geneticists and breeders. Initially, a different origin for each subspecies (see below) was advanced based on the morphological variability and their partial reproductive isolation (Singh and Moss, 1982; Lu and Pickersgill, 1993). However, most authors now support the hypothesis that $A$. hypogaea is an allotetraploid derived from just two wild diploid species, and indeed probably between very few individuals of these diploid species. This is supported by the very limited genetic variability among landraces and commercial cultivars of $A$. hypogaea, and from its molecular cytogenetics (Halward et al., 1991; Kochert et al., 1996; Raina et al., 2001; Seijo et al., 2004, 2007; Milla et al., 2005). It is also apparent that the wild tetraploid A. monticola is very closely related to A. hypogaea; indeed, they most probably share the same origin and are the same biological species. They have very high crossability, cytogenetically the species are indistinguishable, and molecular studies show they are very closely related. They could not be differentiated based on isozymes (Lu and Pickersgill, 1993), random amplified polymorphic DNA (RAPD; Hilu and Stalker, 1995; Cunha et al., 2008) and some microsatellite markers (Gimenes et al., 2007; Koppolu et al., 2010). However, various studies, based on amplified fragment length polymorphism (AFLP), microsatellite and sequence-related amplified polymorphism markers, have shown that A. monticola does have enough genetic divergence to form a separate group (Gimenes et al., 2002; Moretzsohn et al., 2004; Milla et al., 2005; Bravo et al., 2006; Ren et al., 2010).

Based on the evidence cited above, on whole genome in situ hybridization and on biogeographic information (Fig. 3; also see below), it is currently accepted that A. duranensis (AA genome) and A. ipaënsis (BB genome) are the most probable ancestors of $A$. monticola and A. hypogaea (Fernández and Krapovickas, 1994; Kochert et al., 1996; Seijo et al., 2004; Seijo et al., 2007). These species, either by hybridization followed by chromosome duplication or by fusion of unreduced gametes, produced an AABB genome individual, probably A. monticola or a similar wild tetraploid. This event may have occurred in the wild, or spontaneously when the two diploids were cultivated in close proximity by ancient inhabitants of South America. Morphologically diverse landraces of peanut could then have arisen by artificial selection of the polyploid in different agroecological environments by ancient South American itinerant farmers (Krapovickas, 2004).

As for the geographical origin, archaeological studies indicate the presence of $A$. hypogaea in the Huarmey Valley in Peru (5000 year BP) (Bonavia, 1982) and of pod samples that strongly resemble those of wild species, in the Casma Valley also in Peru (3500 and 3800 year BP). These locations are perfect for the preservation of archaeological specimens because of their dry climates, but are far from the present day natural distribution of wild Arachis. This strongly suggests that ancient peoples were cultivating Arachis in northwest Peru, and it is even possible that these sites were the location of origin of $A$. hypogaea (Simpson and Faries, 2001). However, it seems more likely that this occurred in moister environments where there are more abundant populations of bees that could serve as agents for cross pollination. The morphological variability of the landraces, the distributions of the putative $\mathrm{A}$ and $\mathrm{B}$ genome donors and the location of $A$. monticola place the most likely location origin of the domesticated peanut in northern Argentina and southern Bolivia, in a transition area between the Tucumano-Bolivian forest and the Chaco lowlands (Fig. 3; Gregory et al., 1980; Krapovickas and Gregory, 1994).

\section{The genetic behaviour of peanut}

From genetic maps, it is apparent that the order of molecular markers in the A and B genomes is mostly co-linear with only a few major rearrangements that distinguish them (Burow et al., 2001; Moretzsohn et al., 2009). This emphasizes the similarity of the two genome components. However, the $\mathrm{A}$ and $\mathrm{B}$ genomes must have important differences because cultivated peanut is an allotetraploid that is well diploidized genetically; almost all chromosome pairing during meiosis is bivalent, and no large chromosome rearrangements between the $\mathrm{A}$ and $\mathrm{B}$ genome components seem to have occurred after the formation of the tetraploid species (Smartt, 1990; Seijo et al., 2007). The nature of the differences between the genomes that prevent efficient pairing in meiosis is unknown, but recent studies 

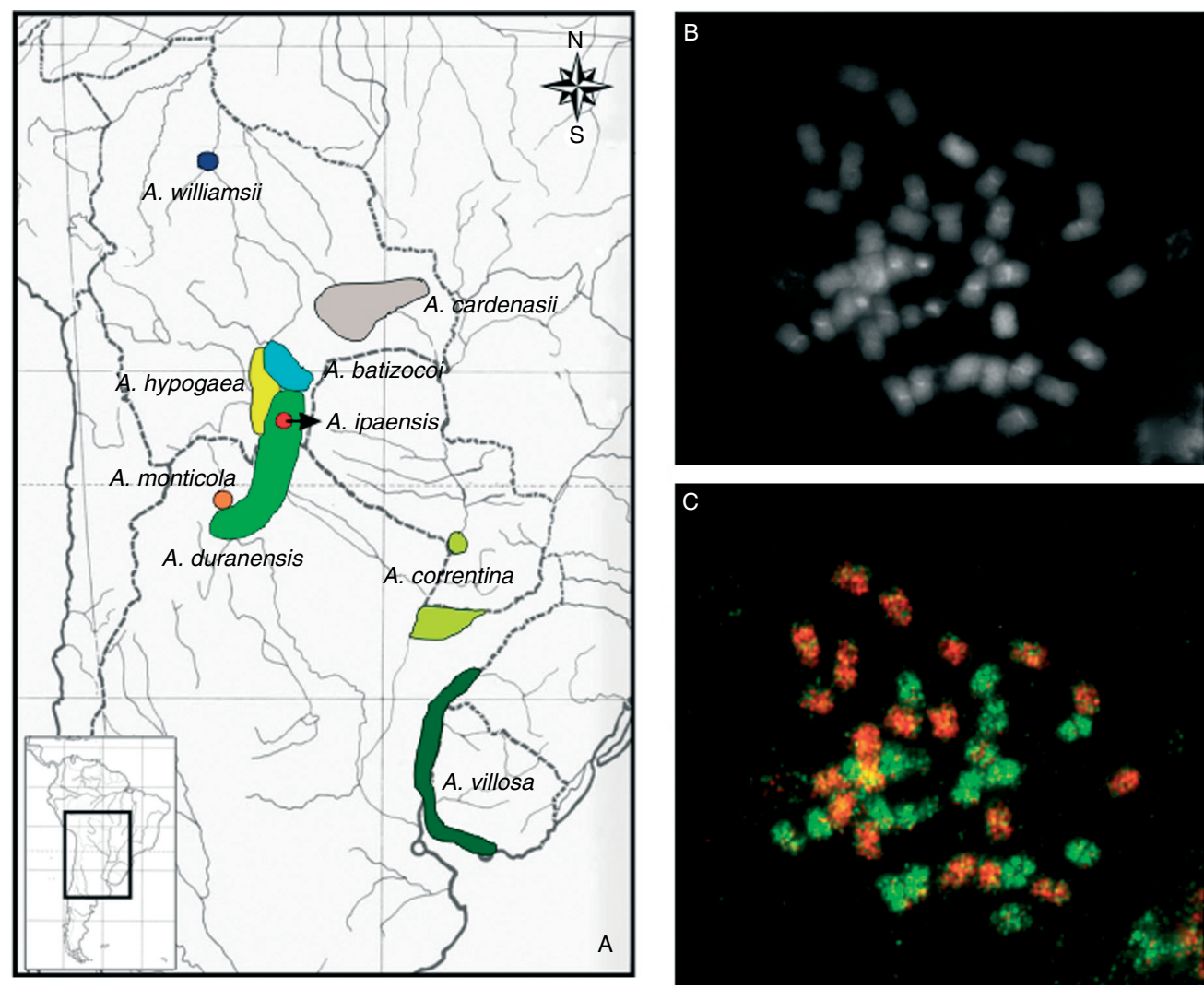

D

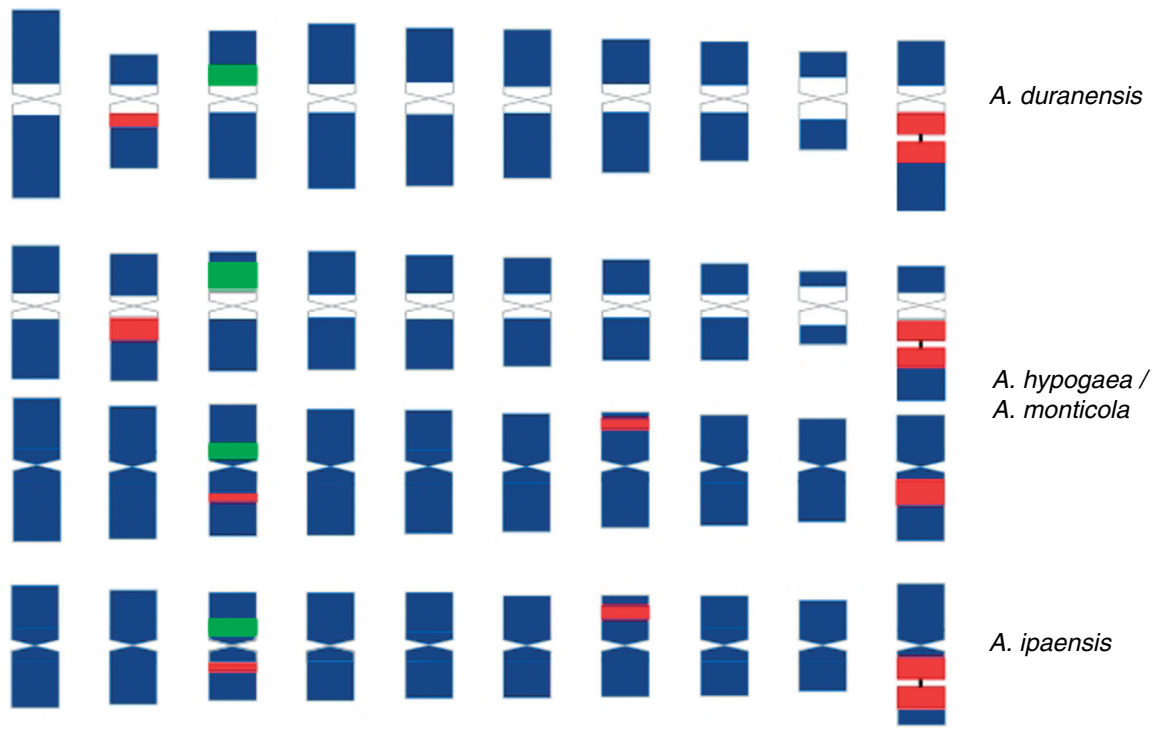

Fig. 3. (A) Geographic distribution of the putative wild progenitors of peanut and the major centre of variability of Arachis hypogaea var. hypogaea (adapted from Seijo et al. (2004)). (B) Somatic metaphases of A. hypogaea after 4-6-diamidino-2phenylindole (DAPI) staining showing half of the chromosomes with heterochromatic bands. (C) Same metaphase after double genomic in situ hybridization using total DNA probes from Arachis ipaensis (red) and Arachis duranensis (green) (B and C from Seijo et al. (2007)). (D) Idiograms of A. hypogaea/A. monticola and their most probable wild ancestors (A. duranensis and $A$. ipaensis) showing the distribution of 5S (green) and 18S-25S (red) rDNA loci, and the DAPI-enhanced heterochromatic bands (white) (adapted from Seijo et al. (2004)). 
may have some bearing on this. In situ hybridization analysis performed with genomic DNA of wild species onto the chromosomes of $A$. hypogaea suggests that genome differentiation in Arachis section may have been accompanied by rapid divergence in the content of the repetitive elements (Seijo et al., 2007). A closer analysis of the abundance, distribution and evolution of one Ty3-gypsy element, called FIDEL, on the A and B genomes supports this (Nielen et al., 2010).

\section{Variation within cultivated peanut}

It was perhaps Charles Darwin who first noted that domesticated species accumulate a remarkable amount of variation in a short time. Peanut follows this pattern, and considering its very recent origin, it exhibits a remarkable amount of morphological variability. Based on this, two subspecies were recognized, hypogaea and fastigiata. These, in turn, have two (hypogaea and birsuta) and four (fastigiata, vulgaris, aequatoriana and peruviana) botanical varieties, respectively (Fig. 4; Krapovickas and Gregory, 1994).

The type variety ( $A$. bypogaea subsp. bypogaea var. hypogaea) has a long cycle, no flowers on the central stem, and regularly alternating vegetative and reproductive side stems. It is widely present as landraces along the tributaries to the South of the Amazon River in Brazil and Bolivia. The modern agricultural types 'Virginia' or 'Runner' exemplify this type. Also classified within subsp. hypogaea, but with more hirsute leaflets and even longer cycle, is the variety birsuta Köhler (Peruvian Runner). Nowadays, this variety is concentrated in the coastal regions of Peru, from where it extends to Central America and Mexico, Asia and Madagascar. The variability of this variety found in the Old World even suggests the possibility of preColombian contacts.

The subspecies fastigiata Waldron has a shorter cycle, flowers on the central stem and reproductive and vegetative stems distributed in a disorganized way. The variety vulgaris $\mathrm{C}$. Harz has its distribution centred on the basin of the river Uruguay. Usually, the fruits are two seeded, and the varieties correspond to the agricultural type known as 'Spanish'. The variety fastigiata has fruits with more than two seeds and a smooth pericarp; this variety corresponds to the agricultural type 'Valencia'; centres of diversity are in Paraguay, and Central and North-Eastern Brazil extending to Peru. The other two varieties aequatoriana Krapov. and W.C. Gregory (Ecuador and North of Peru) and peruviana Krapov. and W.C. Gregory (Peru, North East of Bolivia and the Brazilian State of Acre) have fruits with more than two seeds, heavy reticulation of the pericarp and very restricted distributions.

Initially, the very limited DNA polymorphism present in $A$. hypogaea limited the information that could be gained from molecular studies. The first studies were based on isozymes and proteins (Krishna and Mitra, 1988; Grieshammer and Wynne, 1990; Lu and Pickersgill, 1993), followed by restriction fragment length polymorphism - RFLPs (Kochert et al., 1991, 1996; Paik-Ro et al., 1992), RAPDs (Halward et al., 1991; 1992; Hilu and Stalker, 1995; Subramanian et al., 2000; Dwivedi et al., 2001) and AFLPs (He and Prakash, 1997, 2001; Gimenes et al., 2002; Herselman, 2003; Milla et al., 2005; Tallury et al., 2005). None of these marker systems were very informative in cultivated germplasm. Higher levels of polymorphism were observed with microsatellites, in particular with longer TC motif repeats (Moretzsohn et al., 2005). Over the last few years, many new microsatellite markers have been developed, and this has enabled the detection of moderate levels of genetic variation in $A$. bypogaea accessions and even intravariety polymorphism (Krishna et al., 2004; Barkley et al., 2007; Tang et al., 2007; Varshney et al., 2009c). These studies have shown the grouping of accessions according to the varieties they belong to ( Jiang et al., 2007; Kottapalli et al., 2007). In general, two main groups were observed, joining accessions of $A$. hypogaea ssp. fastigiata 'fastigiata' (Valencia type) and fastigiata 'vulgaris' (Spanish type) in one group, and bypogaea 'bypogaea' (Virginia and

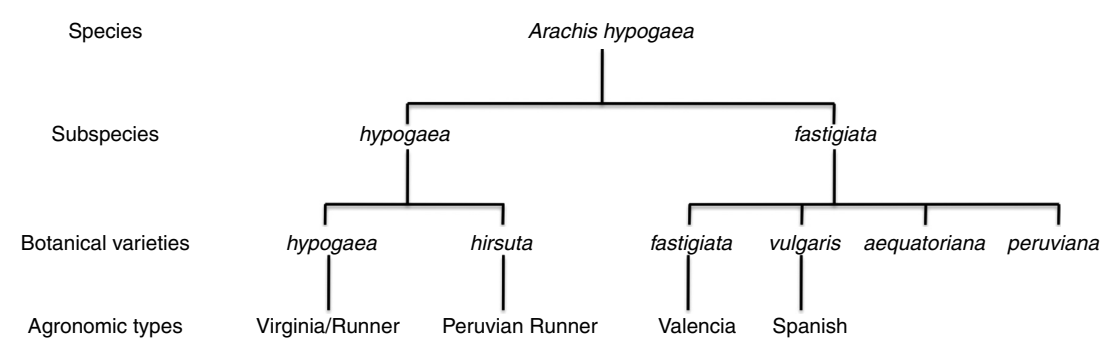

Fig. 4. The taxonomic arrangement of subspecies and botanical varieties of Arachis hypogaea, and their equivalence to agronomic types. It should be noted that many modern cultivars are of mixed parentage and are not good representatives of the botanical varieties. 
Runner types) and bypogaea 'birsuta' (Peruvian runner) in a second group. These results corroborated the current taxonomic status of these subspecies and varieties. Exceptions to these results may be explained by the erroneous use of modern cultivars or breeding lines to represent the varieties. Frequently, these cultivars/lines have different varieties in their pedigrees and do not represent the varieties as well as landraces do. However, in contrast, studies that included fastigiata 'aequatoriana' and, especially, fastigiata 'peruviana' accessions raised questions on the current classification of these varieties (He and Prakash, 2001; Raina et al., 2001; Ferguson et al., 2004a; Tallury et al., 2005; Freitas et al., 2007; Cuc et al., 2008). Most of them have shown that accessions of these varieties have greater similarity to subspecies hypogaea rather than to subspecies fastigiata, to which they are currently thought to belong; the exception being the study of Moretzsohn et al., 2004. However, only a small number of fastigiata 'aequatoriana' and fastigiata 'peruviana' accessions were included in these studies, and we consider that more investigation is required to reach firm conclusions.

\section{Landraces}

South America's history, past and present, is of a tapestry of peoples living in very different environments and circumstances, of displacements, and migrations. Over much of the region, where the climate is suitable, this history is intrinsically tied to the evolution and maintenance of diverse landraces and types of peanut. The changes that were initiated some 500 years ago with the discovery of the Americas by Europeans have steadily increased in impact and speed to the present day. Now South America has some of the largest urban centres in the World and some isolated communities that have never been in contact with the modern World. Many landraces must have been lost during these changes, but many survived. Numerous landraces are grown by South Americans of mixed descent, sometimes using cultivation methods such as companion planting with cassava, that were obviously used by pre-Colombian native peoples. Recently, a very interesting description of 62 distinct landraces in Bolivia has been published (Krapovickas et al., 2009). Almost all of these landraces are endemic to the country.

Many landraces are cultivated by more isolated communities and remain poorly characterized or unknown to science. These landraces are of particular interest because they may have new valuable characteristics. However, they are also vulnerable to extinction during the social upheavals that seem inevitable when native and modern societies meet. Below we shall give a brief description of two such cases.

Williams (1996) described the very interesting cultivation of landraces by native farmers in Eastern Bolivia.
They plant in very unusual conditions, the beaches, or sandbanks of rivers that are exposed for a rather short period during the dry season. Under this cropping system, the plants suffer strong selection pressure for uniform germination and a very short cycle, because they must produce seed before the water rises again and inundates the growing area.

Another very interesting case has been coming to light recently of the Kayabi Indians who live in the Xingu Indigenous Park in the Central West of Brazil. The park was officially created in 1961 and covers $30,000 \mathrm{~km}^{2}$, almost the size of Belgium. It is located in a transition area between biomes, with the Cerrado to the South and the Amazon to the North. Indians from a number of distinct ethnic groups originally inhabited the park, and some others, including the Kayabi, were transferred there. Now there are 14 villages of the Kayabi living in the Park, and peanut is important to them both as a food and culturally. Some villages cultivate only two or three types of peanut, but others many more, some 60 types being recognized by the Indians themselves. The types are morphologically very diverse, and their combinations of unusual characters make them unique. Some types are very large and have a very long cycle, and some have extremely large seeds. Some types have very tough pods, and others have thin pods. Seeds are purple, brown, red or white, some types having a uniform colour, others being partly coloured and partly white (Fig. 5).

The peanuts are cultivated in a slash and burn system. Within an area of forest, the smaller vegetation is cut in

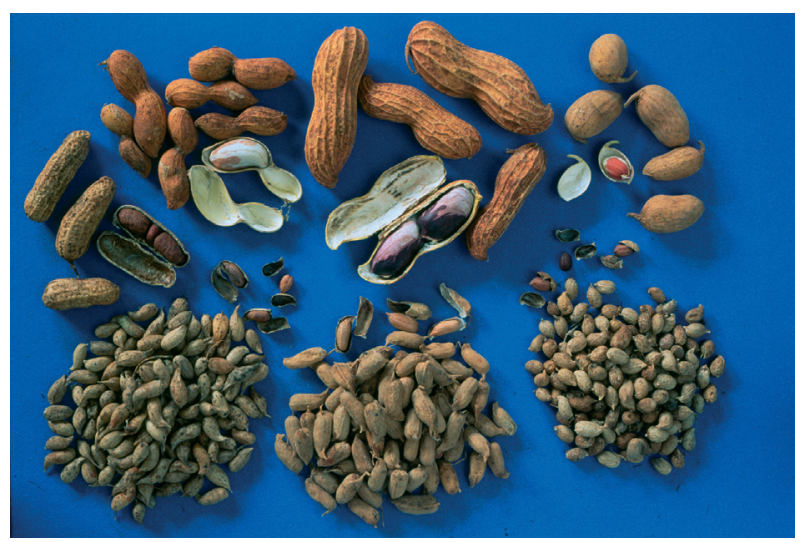

Fig. 5. A selection of cultivated peanuts and their wild relatives. The groups of pods and seeds are, starting from top left and going clockwise: Of107, Of128 and Of111, three types of cultivated peanut (Arachis hypogaea) kindly given to Fábio de Oliveira Freitas by the Kayabi South American Indians; Arachis cardenasii, Arachis stenosperma and Arachis duranensis are the three wild diploid species. Note that the long thread-like isthmus, which separates the seeds in the pods, has broken during harvesting; Arachis hypogaea var. fastigiata cv. Tatu, a popular cultivar of peanut in Brazil. 
May/June. This is then left during the dry season, and the area is cleared by burning in August, just before the start of the rains. Areas with more fertile black soils are chosen, and are cultivated for several years. The different types of peanut have cycles of different lengths, and planting is programmed such that all the peanuts can be collected together. At the beginning of the season, women select the seeds and men do the planting. At the end of the season, women harvest the plants simply by pulling them from the ground. The larger runner-type plants come loose after a series of pulls starting at one edge of the plant and working over to the other edge. After harvesting, the peanuts are dried and stored all mixed together, in pod, in enormous baskets (Fig. 6). Peanuts are taken from these baskets for consumption starting at the top, and those left at the bottom are used for seed at the beginning of the next season.

Thirty samples of this material were analyzed from two Kayabi villages using microsatellite markers along with a selection of other cultivated and wild accessions. With the exception of one pair, all Kayabi samples could be distinguished, and the samples formed three deep-rooted clades within the dendrogram, reflecting their genetic distinctness. Of particular interest was an

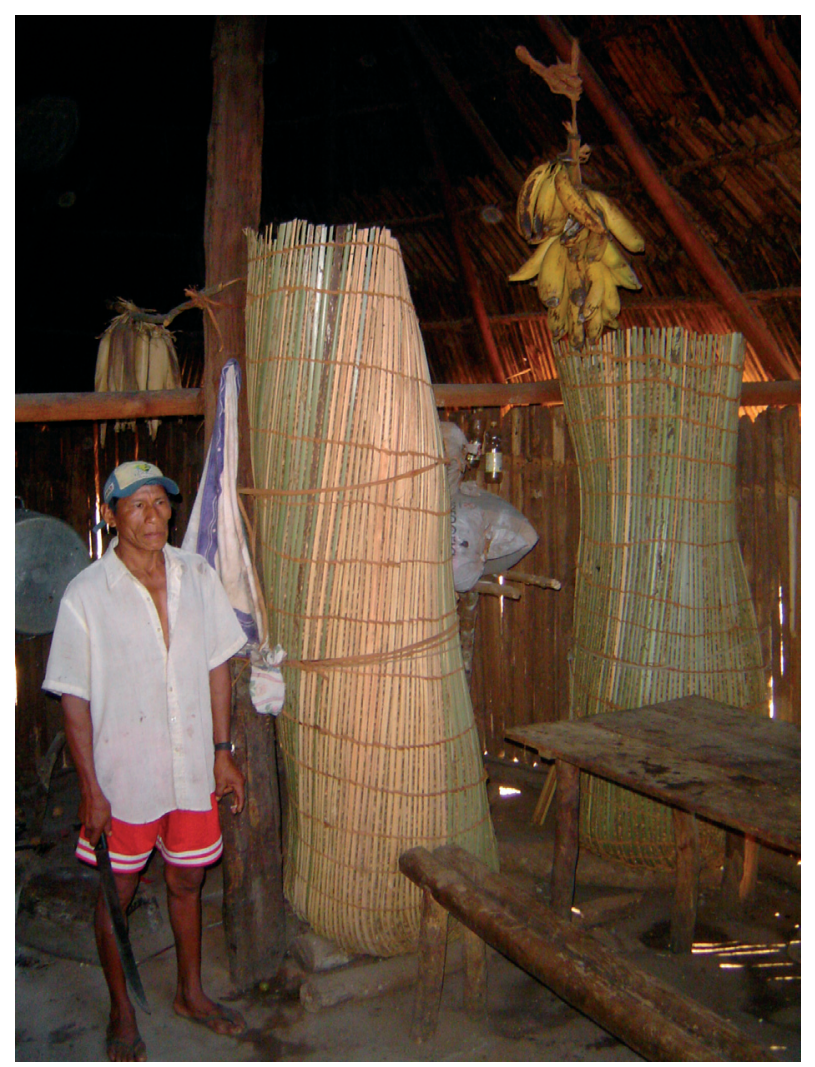

Fig. 6. A Kayabi man next to the large baskets used to store peanuts. accession that, although not wild in phenotype in any obvious way, grouped closest to the wild tetraploid $A$. monticola. Amazingly, this accession had been described by the Indians as the most ancient of the peanuts, and was known to them as 'peanut of the field' (Freitas et al., 2007). We hope that this story serves to illustrate the diversity of peanut landraces that still awaits discovery by science, and that it also provides a glimpse of how traditional knowledge may enhance our understanding of germplasm.

\section{Germplasm banks}

Important collections of germplasm are held at ICRISAT, India; the USDA-ARS, USA; INTA, Argentina; PROINPA, Bolivia; EMBRAPA-Cenargen, Brazil; IBONE, Argentina and Texas A\&M, USA. The first four collections mentioned concentrate on cultivated peanut, and the latter three collections focus more on wilds. Structured core collections of cultivated peanut have been assembled of 1704 and 831 accessions, and mini-cores of 184 and 112 accessions at ICRISAT and USDA-ARS, respectively (Holbrook et al., 1993; Varshney et al., 2009b). These cores and mini-cores are an efficient way to access greater diversity in breeding programmes, and are being widely used. There are numerous other collections of peanut germplasm maintained around the world, most of them being focused on cultivated peanut at institutions that have, or are linked to, breeding programmes.

\section{The use of wild germplasm in peanut breeding}

As a consequence of having duplicated genomes, the tetraploid that gave rise to $A$. hypogaea would have been isolated from sharing genes with its wild relatives. Therefore, a strong genetic bottleneck was created at the origin of the tetraploid species. In spite of this, the variation that has accumulated in peanut during artificial selection over thousands of years of domestication provides a rich material for breeding for many traits. This is the case, for example, with seed and pod characteristics and growth habit. However, for other characteristics such as disease and pest resistance, the narrow genetic base presents clear limitations to crop improvement. There are also good theoretical reasons to believe that genetic limits for more complex traits such as yield and drought tolerance can be overcome by broadening the genetic base of the crop. For these reasons, for many years, peanut breeders have been interested in the introduction of new alleles from wild species.

The transfer of genes from wild species by crossing has faced three fundamental problems: fertility barriers 
caused by species incompatibilites and ploidy differences; linkage drag of desirable wild alleles with ones that confer agronomically unadapted traits; and difficulties in confirming hybrid identities and tracking introgressed segments. Together, these problems are considerable, but as the knowledge base, and tools available improve, the ability to overcome them also improves. As outlined earlier in this manuscript, research over the last few years has provided a much better understanding of the origin of cultivated peanut and the relationships of the species that are closely related to its $\mathrm{A}$ and $\mathrm{B}$ genome components. This has effectively expanded the secondary gene pool. Furthermore, considerable effort has been invested in the creation of the tools needed for hybrid identification, tracking of introgressed segments and for the genetic analysis necessary to understand linkage drag. The number of molecular markers, in particular microsatellite markers, has increased enormously over the last few years. Microsatellites are currently the markers of choice for peanut since they are co-dominant, highly polymorphic, transferable among related species, PCR-based and work easily in the tetraploid. Now more than 3000 markers are available (Hopkins et al., 1999; Palmieri et al., 2002, 2005; He et al., 2003, 2005; Moretzsohn et al., 2004, 2005, 2009; Ferguson et al., 2004b; Bravo et al., 2006; Budiman et al., 2006; Martins et al., 2006; Gimenes et al., 2007; Proite et al., 2007; Wang et al., 2007; Cuc et al., 2008; Guo et al., 2008; Liang et al., 2009; Moretzsohn MC, de Macedo SE, Leal-Bertioli SCM, Guimarães PM and Bertioli DJ, unpublished data). Furthermore, reference genetic maps, both in diploid $\mathrm{A}$ and $\mathrm{B}$ and in tetraploid genomes, have been created enabling the comparison of different peanut maps, and even allowing the alignment of maps with other legume species (Hougaard et al., 2008; Bertioli et al., 2009; Leal-Bertioli et al., 2009; Moretzsohn et al., 2009; Varshney et al., 2009a).

A number of methods have been used for the introgression of wild genes in cultivated peanut, with variable success, but here we shall cover two methods that have resulted in well-characterized introgressions: the hexaploid and tetraploid routes.

The hexaploid route was used by Stalker et al. (1979) who generated a triploid hybrid from a cross between the tetraploid $A$. hypogaea and the diploid $A$. cardenasii. The resulting hybrid was colchicine treated to create a hexaploid plant, and after five generations of selfing, all plants were tetraploid (Stalker et al., 1979). Selected lines were released with resistance to multiple disease resistances (Stalker and Beute, 1993; Reddy et al., 1996). These lines were characterized using RFLP and RAPD markers, and this showed that introgression was widespread (Garcia et al., 1995). Furthermore, markers linked to root-knot nematode resistance were identified
(Garcia et al., 1996). Recently, more details on the genetics of fungal disease resistances of these lines have been obtained. A population derived from a cross of the peanut cultivar TAG24 with one of the lines (GPBD 4) was used for the identification of quantitative trait loci (QTLs) for rust and late leaf spot resistance (Khedikar et al., 2010).

The tetraploid route was first used by Simpson (1993) to create a wild-derived tetraploid. Firstly, an A genome hybrid was made by crossing $A$. cardenasii with A. diogoi. Then, the B genome s.l. species A. batizocoi was crossed with the A genome hybrid to create a sterile $\mathrm{AB}$ hybrid. This was treated with colchicine to double the chromosome number and restore fertility. This tetraploid $[\text { A. batizocoi } \times(A \text {. cardenasii } \times A \text {. diogoi })]^{4 x}$ was registered as TxAG-6 (Simpson et al., 1993). Because of the method used to produce it and its genetic behaviour, this hybrid is usually referred to as an amphidiploid. Hybrids between cultivated peanut and TxAG-6 have low fertility, but a BC-1 population and the first tetraploid map of peanut were developed from it using the peanut cultivar Florunner as the recurrent parent (Burow et al., 2001). TxAG-6 has very strong nematode resistance, but also presents very strong linkage drag to low yield. RFLP markers linked to nematode resistance were used to substantially break this linkage in the development of the nematode-resistant variety NemaTAM (Church et al., 2000; Simpson et al., 2003). Recently, a detailed study by Nagy et al. (2010) used microsatellite and resistance gene analogue markers, and diploid and tetraploid mapping populations to show that the introgressed chromosome segment displayed strongly suppressed recombination with cultivated peanut, and spanned an amazing one-third to one-half of an entire chromosome. Numerous co-dominant DNA markers were identified within the segment, opening up the perspective of finer mapping of the resistance gene and of shortening the introgressed segment by marker-assisted selection. A set of introgression lines from TxAG- 6 that cover other parts of the genome are in the final phase of development, and are being characterized by RFLP and microsatellite markers (Dr Mark Burow, Texas A\&M University, pers. commun.). These lines have great potential to serve as donors of other valuable wild genes.

Recently, also using the tetraploid route, introgression work has been done using a synthetic amphidiploid produced from the proposed ancestors of cultivated peanut, (A. ipaënsis $\times$ A. duranensis) ${ }^{4 x}$ (Fávero et al., 2006). Using the cultivar Fleur 11 as the recurrent parent and the amphidiploid as donor, $\mathrm{BC}_{1}$ plants were used to construct a microsatellite-based genetic map. To confirm linkage order, the map was aligned with diploid reference maps (Bertioli et al., 2009; Moretzsohn et al., 2009) and, using the genotyping information, 
a subset of $\mathrm{BC}_{1} \mathrm{~s}$ was selected for further backcrossing. The progeny plants were again genotyped, and a set of $59 \mathrm{BC}_{2}$ plants that represented the entire donor genome were again selected for backcrossing. In the $\mathrm{BC}_{2} \mathrm{~F}_{1}$ plants, segment lengths ranged between 2.3 and $46.9 \mathrm{cM}$ (mean of $24.5 \mathrm{~cm}$ ), and the percentage of the recurrent background ranged between 62 and 94\% (Foncéka et al., 2009). In work that has run in parallel, lines have been developed using a different recurrent parent, IAC-Runner 886 (a selection of Florunner), and the same amphidiploid donor. Using a combination of genotyping and phenotyping, 12 lines have been selected at $\mathrm{BC}_{1} \mathrm{~F}_{3}$ that combine agronomically adapted phenotypes with resistance to late leaf spot (Leal-Bertioli, 2010; Leal-Bertioli SCM, Moretzsohn MC, Guimarães PM and Bertioli DJ, unpublished results). These results are promising, but it is evident that the disease resistances of this amphidiploid are not as strong as in some other wild species. Recently, we have been exploring the potential of $A$. stenosperma, from which amphidiploids have been obtained (Santos SP, Leal-Bertioli SCM, Moretzsohn MC and Bertioli DJ, unpublished results). A. stenosperma has strong resistances against rust, leaf spots and root-knot nematodes (Proite et al., 2008; LealBertioli et al., 2010). Apart from segregation distortion, genetically it behaves in an apparently normal way when crossed with $A$. duranensis, and QTLs for resistance against late leaf spot have been identified (Leal-Bertioli et al., 2009). Presently, we are gathering phenotypic and genotypic data from hybrids between cultivated peanut and these new amphidiploids. Further analysis will reveal their potential.

\section{Conclusions}

The genus Arachis has a unique biology and unusually complex taxonomy. In spite of this, the overall view of the relationships of the species within the genus, while by no means completely defined, has a firm basis and is consistent and well organized. Cultivated peanut is a very important food crop throughout the tropics and sub-tropics. Because of its allotetraploid origin, it has a very narrow genetic base, and this presents fundamental limitations for the improvement of the crop. In contrast, during evolution, wild species have adapted to diverse ecological niches, and have diverse alleles with potential for use in improvement of the peanut crop. To date, various difficulties, both biological and technical, have led to this resource being underutilized. Our improved understanding of the species relationships within the genus, and improved tools for genetic and genomic studies will enable more efficient use of the genetic resources available.

\section{Acknowledgements}

D.J.B. and J.F.M.V. thank CNPq for their fellowship grants.

\section{References}

Barker NP (2005) A review and survey of Basicarpy, Geocarpy, and Amphicarpy in the African and Madagascan flora. Annals of the Missouri Botanical Garden 92: 445-462.

Barkley NA, Dean RE, Pittman RN, Wang ML, Holbrook CC and Pederson GA (2007) Genetic diversity of cultivated and wild-type peanuts evaluated with M13-tailed SSR markers and sequencing. Genetics Research 89: 93-106.

Bechara MD, Moretzsohn MC, Palmieri DA, Monteiro JP, Bacci Júnior M, Valls JFM, Lopes CR and Gimenes MA (2010) Phylogenetic relationships in genus Arachis based on ITS and 5.8S rDNA sequences. BMC Plant Biology 10: 255.

Bertioli DJ, Moretzsohn MC, Madsen LH, Sandal N, Leal-Bertioli SCM, Guimarães PM, Hougaard BK, Fredslund J, Schauser L, Nielsen AM, Sato S, Tabata S, Cannon SB and Stougaard J (2009) An analysis of synteny of Arachis with Lotus and Medicago sheds new light on the structure, stability and evolution of legume genomes. BMC Genomics 10: 45.

Bonavia D (1982) Precerámico peruano, Los Gavilanes, oasis en la bistoria del hombre. Lima: Corporación Financiera de Desarrollo S.A. COFIDE e Instituto Arqueológico Alemán.

Bravo JP, Hoshino AA, Angelici CMLCD, Lopes CR and Gimenes MA (2006) Transferability and use of microsatellite markers for the genetic analysis of the germplasm of some Arachis section species of the genus Arachis. Genetics and Molecular Biology 29: 516-524.

Budiman MA, Jones JIT, Citek RW, Warek U, Bedell JA and Knapp SJ (2006) Methylation-filtered and shotgun genomic sequences for diploid and tetraploid peanut taxa. GenBank Available at http://www.ncbi.nlm.nih.gov/

Burow MD, Simpson CE, Starr JL and Paterson AH (2001) Transmission genetics of chromatin from a synthetic amphidiploid to cultivated peanut (Arachis hypogaea L.): broadening the gene pool of a monophyletic polyploid species. Genetics 159: 823-837.

Cabrera AL and Willink A (1973) Biogeografía de América Latina. Serie Biología, Monografía. vol. 13. Washington, DC: Organización de Estados Americanos, p. 117.

Church GT, Simpson CE, Burow MD, Paterson AH and Starr JL (2000) Use of RFLP markers for identification of individuals homozygous for resistance to Meloidogyne arenaria in peanut. Nematology 2: 575-580.

Cuc LM, Mace ES, Crouch JH, Quang VD, Long TD and Varshney RK (2008) Isolation and characterization of novel microsatellite markers and their application for diversity assessment in cultivated groundnut (Arachis bypogaea L.). BMC Plant Biology 8: 55.

Cunha FB, Nobile PM, Hoshino AA, Moretzsohn MC, Lopes CR and Gimenes MA (2008) Genetic relationships among Arachis hypogaea L. (AABB) and diploid Arachis species with $\mathrm{AA}$ and $\mathrm{BB}$ genomes. Genetic Resources and Crop Evolution 55: 15-20.

Dwivedi SL, Gurtu S, Chandra S, Yuejin W and Nigam SN (2001) Assessment of genetic diversity among selected groundnut germplasm. 1: RAPD analysis. Plant Breeding 120: 345-349.

FAOSTAT (2008) Available at http://faostat.fao.org/ 
Fávero AP, Simpson CE, Valls JFM and Vello NA (2006) Study of the evolution of cultivated peanut through crossability studies among Arachis ipaënsis, A. duranensis, and A. bypogaea. Crop Science 46: 1546-1552.

Ferguson ME, Bramel PJ and Chandra S (2004a) Gene diversity among botanical varieties in peanut (Arachis hypogaea L.). Crop Science 44: 1847-1854.

Ferguson ME, Burow MD, Schulze SR, Bramel PJ, Paterson AH, Kresovich S and Mitchell S (2004b) Microsatellite identification and characterization in peanut ( $A$. bypogaea L.). Theoretical and Applied Genetics 108: 1064-1070.

Fernández A and Krapovickas A (1994) Cromosomas y evolución en Arachis (Leguminosae). Bonplandia 8: 187-200.

Foncéka D, Hodo-Abalo T, Rivallan R, Faye I, Sall MN, Ndoye O, Fávero AP, Bertioli DJ, Glaszmann JC, Courtois B and Rami JF (2009) Genetic mapping of wild introgressions into cultivated peanut: a way toward enlarging the genetic basis of a recent allotetraploid. BMC Plant Biology 9: 103.

Freitas FO, Moretzsohn MC and Valls JFM (2007) Genetic variability of Brazilian Indian landraces of Arachis bypogaea L. Genetics and Molecular Research 6: 675-684.

Garcia GM, Stalker HT and Kochert G (1995) Introgression analysis of an interspecific hybrid population in peanuts (Arachis bypogaea L.) using RFLP and RAPD markers. Genome 38: 166-176.

Garcia GM, Stalker HT, Shroeder E and Kochert G (1996) Identification of RAPD, SCAR and RFLP markers tightly linked to nematode resistance genes introgressed from Arachis cardenasii to A. hypogaea. Genome 39: 836-845.

Gimenes MA, Lopes CR and Valls JFM (2002) Genetic relationships among Arachis species based on AFLP. Genetics and Molecular Biology 25: 349-353.

Gimenes MA, Hoshino AA, Barbosa AVG, Palmieri DA and Lopes CR (2007) Characterization and transferability of microsatellite markers of cultivated peanut (Arachis bypogaea). BMC Plant Biology 7: 9.

Gregory WC, Krapovickas A and Gregory MP (1980) Structure, variation, evolution and classification in Arachis. In: Summerfield RT and Bunting AH (eds) Advances in Legume Science. Kew: Royal Botanic Gardens, pp. 469-481.

Grieshammer U and Wynne JC (1990) Isozyme variability in mature seeds of U.S. peanut cultivars and collections. Peanut Science 17: 72-75.

Guo BZ, Chen X, Dang P, Scully BT, Liang X, Holbrook CC, Yu J and Culbreath AK (2008) Peanut gene expression profiling in developing seeds at different reproduction stages during Aspergillus parasiticus infection. BMC Developmental Biology 8: 12.

Halward TM, Stalker HT, Larue EA and Kochert G (1991) Genetic variation detectable with molecular markers among unadapted germplasm resources of cultivated peanut and related wild species. Genome 34: 1013-1020.

Halward T, Stalker HT, Larue EA and Kochert G (1992) Use of single primer DNA amplifications in genetic studies of peanut (Arachis hypogaea L.). Plant Molecular Biology 18: 315-325.

He G and Prakash CS (1997) Identification of polymorphic DNA markers in cultivated peanut (Arachis bypogaea L.). Euphytica 97: 143-149.

He G and Prakash CS (2001) Evaluation of genetic relationships among botanical varieties of cultivated peanut (Arachis bypogaea L.) using AFLP markers. Genetic Resources and Crop Evolution 48: 347-352.
He G, Meng R, Newman M, Gao G, Pittman RN and Prakash CS (2003) Microsatellites as DNA markers in cultivated peanut (A. bypogaea L.). BMC Plant Biology 3: 3.

He G, Meng R, Gao H, Guo B, Gao G, Newman M, Pittman RN and Prakash CS (2005) Simple sequence repeat markers for botanical varieties of cultivated peanut (Arachis hypogaea L.). Euphytica 142: 131-136.

Herselman L (2003) Genetic variation among Southern African cultivated peanut ( $A$. bypogaea L.) genotypes as revealed by AFLP analysis. Euphytica 133: 319-327.

Hilu KW and Stalker HT (1995) Genetic relationships between peanut and wild species of Arachis sect. Arachis (Fabaceae): evidence from RAPDs. Plant Systematics and Evolution 198: 167-178.

Holbrook CC, Anderson WF and Pittman RN (1993) Selection of a core collection from the U.S. germplasm collection of peanut. Crop Science 33: 859-861.

Hopkins MS, Casa AM, Wang T, Mitchell SE, Dean R, Kochert GD and Kresovich S (1999) Discovery and characterization of polymorphic simple sequence repeats (SSRs) in peanut. Crop Science 39: 1243-1247.

Hougaard BK, Madsen LH, Sandal N, Moretzsohn MC, Fredslund J, Schauser L, Nielsen AM, Rohde T, Sato S, Tabata S, Bertioli DJ and Stougaard J (2008) Legume anchor markers link syntenic regions between Phaseolus vulgaris, Lotus japonicus, Medicago truncatula and Arachis. Genetics 179: 2299-2312.

Husted L (1936) Cytological studies on the peanut, Arachis. II. Chromosome number, morphology and behavior, and their application to the problem of the cultivated forms. Cytologia 7: 396-423.

Jiang H, Liao B, Ren X, Lei Y, Mace E, Fu T and Crouch JH (2007) Comparative assessment of genetic diversity of peanut (Arachis bypogaea L.) genotypes with various levels of resistance to bacterial wilt through SSR and AFLP analyses. Journal of Genetics and Genomics 34: $544-554$.

Khedikar YP, Gowda MVC, Sarvamangala C, Patgar KV, Upadhyaya HD and Varshney RV (2010) A QTL study on late leaf spot and rust revealed one major QTL for molecular breeding for rust resistance in groundnut (Arachis bypogaea L.). Theoretical and Applied Genetics. DOI: 10.1007/s00122-010-1366-x (online first).

Kochert G, Halward T, Branch WD and Simpson CE (1991) RFLP variability in peanut (Arachis hypogaea) cultivars and wild species. Theoretical and Applied Genetics 81: $565-570$.

Kochert G, Stalker HT, Gimenes M, Galgaro L, Lopes CR and Moore K (1996) RFLP and cytogenetic evidence on the origin and evolution of allotetraploid domesticated peanut, Arachis bypogaea (Leguminosae). American Journal of Botany 83: 1282-1291.

Koppolu R, Upadhyaya HD, Dwivedi SL, Hoisington DA and Varshney RK (2010) Genetic relationships among seven sections of genus Arachis studied by using SSR markers. BMC Plant Biology 10: 15.

Kottapalli KR, Burow MD, Burow G, Burke J and Puppala N (2007) Molecular characterization of the U.S. peanut mini core collection using microsatellite markers. Crop Science 47: 1718-1727.

Krapovickas A (2004) Consideraciones prehistóricas sobre el origen del maní cultivado. Academia Nacional de Agronomia y Veterinaria 58: 320-331. 
Krapovickas A and Gregory WC (1994) Taxonomía del género Arachis (Leguminosae). Bonplandia 8: 1-186.

Krapovickas A and Gregory WC (2007) Taxonomy of the genus Arachis (Leguminosae). Translated by DE Williams, CE Simpson. Bonplandia 16: 1-205.

Krapovickas A, Vanni RO, Pietrarelli JR, Williams DE and Simpson CE (2009) Las Razas de Maní de Bolivia. Bonplandia 18: 95-189.

Krishna TG and Mitra R (1988) The probable genome donors to Arachis bypogaea $\mathrm{L}$. based on arachin seed storage protein. Euphytica 37: 47-52.

Krishna GK, Zhang J, Burow M, Pittman RN, Delikostadinov SG, Lu Y and Puppala N (2004) Genetic diversity analysis in Valencia peanut (Arachis hypogaea L.) using microsatellite markers. Celular and Molecular Biology Letters 9: 685-697.

Lavia GI (1996) Estudios cromosómicos en Arachis (Leguminosae). Bonplandia 9: 111-120.

Lavia GI (1998) Karyotypes of Arachis palustris and A. praecox (Section Arachis), two species with basic chromosome number $x=9$. Cytologia 63: 177-181.

Lavia GI (1999) Caracterización cromosómica del germoplasma de mani. PhD Thesis, Universidad Nacional de Córdoba, Cordoba.

Lavia GI, Ortiz AM and Fernández A (2009) Karyotypic studies in wild germoplasm of Arachis (Leguminosae). Genetic Resources and Crop Evolution 56: 755-764.

Leal-Bertioli SCM, José ACVF, Alves-Freitas DMT, Moretzsohn MC, Guimarães PM, Nielen S, Vidigal BS, Pereira RW, Pike J, Fávero AP, Parniske M, Varshney RK and Bertioli DJ (2009) Identification of candidate genome regions controlling disease resistance in Arachis. BMC Plant Biology 9: 112.

Leal-Bertioli SCM, de Farias MP, Silva PIT, Guimarães PM, Brasileiro ACM, Bertioli DJ and de Araujo ACG (2010) Ultrastructure of the initial interaction of Puccinia arachidis and Cercosporidium personatum with leaves of Arachis hypogaea and Arachis stenosperma. Journal of Phytopathology (online first)

Leal-Bertioli SCML (2010) Characterization of disease resistances in wild Arachis and introgression of wild genes in peanut (Arachis hypogaea) breeding. Vth International Congress on Legume Genetics and Genomics, Asilomar Conference Grounds, Pacific Grove, California, July 2-8.

Lewis G, Schrire B, Muackinder B and Lock M (eds) (2005) Legumes of the World. Kew: Royal Botanic Gardens.

Liang X, Chen X, Hong Y, Liu H, Zhou G, Li S and Guo B (2009) Utility of EST-derived SSR in cultivated peanut (Arachis bypogaea L.) and Arachis wild species. BMC Plant Biology 9: 35 .

Lu J and Pickersgill B (1993) Isozyme variation and species relationships in peanut and its wild relatives (Arachis L. Leguminosae). Theoretical and Applied Genetics 85: $550-560$.

Martins W, de Sousa D, Proite K, Guimarães P, Moretzsohn M and Bertioli DJ (2006) New softwares for automated microsatellite marker development. Nucleic Acids Research 34: e31.

Meney KA, Pate JS and Dixon KW (1990) Comparative morphology, anatomy, phenology and reproductive-biology of Alexgeorgea spp. (Restionaceae) from South-western Australia. Australian Journal of Botany 38: 523-541.

Milla SR, Isleib TG and Stalker HT (2005) Taxonomic relationships among Arachis sect. Arachis species as revealed by AFLP markers. Genome 48: 1-11.
Moretzsohn MC, Hopkins MS, Mitchell SE, Kresovich S, Valls JFM and Ferreira ME (2004) Genetic diversity of peanut (Arachis hypogaea L.) and its wild relatives based on the analysis of hypervaraible regions of the genome. $B M C$ Plant Biology 4: 11.

Moretzsohn MC, Leoi L, Proite K, Guimarães PM, Leal-Bertioli SC, Gimenes MA, Martins WS, Valls JFM, Grattapaglia D and Bertioli DJ (2005) A microsatellite-based gene-rich linkage map for the A-genome of Arachis (Fabaceae). Theoretical and Applied Genetics 111: 1060-1071.

Moretzsohn MC, Barbosa AVG, Alves-Freitas DMT, Teixeira C, Leal-Bertioli SCM, Guimarães PM, Pereira RW, Lopes CR, Cavallari MM, Valls JFM, Bertioli DJ and Gimenes MA (2009) A linkage map for the B-genome of Arachis (Fabaceae) and its synteny to the A-genome. BMC Plant Biology 9: 40 .

Nagy E, Chu Y, Guo Y, Khanal S, Tang S, Li Y, Dong W, Timper P, Taylor C, Holbrook CC, Beilinson V, Nielsen N, Stalker TH and Knapp SJ (2010) Recombination is Suppressed in an alien introgression in peanut harboring Rma, a dominant root-knot nematode resistance gene. Molecular Breeding 26: 357-370.

Nielen S, Campos-Fonseca F, Leal-Bertioli S, Guimarães P, Seijo JG, Town C, Cook D, Arrial R and Bertioli D (2010) FIDEL - a retrovirus-like retrotransposon and its distinct evolutionary histories in the A and B-genome components of cultivated peanut. Chromosome Research 18: 227-246.

Paik-Ro OG, Smith RL and Knauft DA (1992) Restriction fragment length polymorphism evaluation of six peanut species within the Arachis section. Theoretical and Applied Genetics 84: 201-208.

Palmieri DA, Hoshino AA, Bravo JP, Lopes CR and Gimenes MA (2002) Isolation and characterization of microsatellite loci from the forage species Arachis pintoi (Genus Arachis). Molecular Ecology Notes 2: 551-553.

Palmieri DA, Bechara MD, Curi RA, Gimenes MA and Lopes CR (2005) Novel polymorphic microsatellite markers in section Caulorrhizae (Arachis, Fabaceae). Molecular Ecology Notes 5: $77-79$.

Peñaloza APS and Valls JFM (1997) Contagem do número cromossômico em acessos de Arachis decora (Leguminosae). In: Veiga RFA, Bovi MLA, Betti JA and Voltan RBQ (eds) Simpósio Latino-Americano de Recursos Genéticos Vegetais, vol. 1, 1997, Campinas. Programas e Resumos. Campinas: IAC/Embrapa-Cenargen, p. 39.

Proite K, Leal-Bertioli SCM, Bertioli DJ, Moretzsohn MC, da Silva FR, Martins NF and Guimarães PM (2007) ESTs from a wild Arachis species for gene discovery and marker development. BMC Plant Biology 7: 7.

Proite K, Carneiro R, Falcão R, Gomes A, Leal-Bertioli S, Guimarães P and Bertioli D (2008) Post-infection development and histopathology of Meloidogyne arenaria race 1 on Arachis spp. Plant Pathology 57: 974-980. DOI: $10.1111 / \mathrm{j} .1365-3059.2008 .01861 . \mathrm{x}$

Raina SN, Rani V, Kojima T, Ogihara Y, Singh KP and Devarumath RM (2001) RAPD and ISSR fingerprints as useful genetic markers for analysis of genetic diversity, varietal identification, and phylogenetic relationships in peanut (Arachis bypogaea) cultivars and wild species. Genome 44: 763-772.

Reddy LJ, Nigam SN, Moss JP, Singh AK, Subrahmanyam P, McDonald D and Reddy AGS (1996) Registration of ICGV 86699 Peanut Germplasm line with multiple disease and insect resistance. Crop Science 36: 821. 
Ren X, Huang J, Liao B, Zhang X and Jiang H (2010) Genomic affinities of Arachis genus and interspecific hybrids were revealed by SRAP markers. Genetic Resources and Crop Evolution 57: 903-913.

Robledo G and Seijo G (2010) Species relationships among the wild B genome of Arachis species (section Arachis) based on FISH mapping of rDNA loci and heterochromatin detection: a new proposal for genome arrangement. Theoretical and Applied Genetics. DOI: 10.1111/j.13653059.2008.01861.x (online first).

Robledo G, Lavia GI and Seijo JG (2009) Species relations among wild Arachis species with the A genome as revealed by FISH mapping of rDNA loci and heterochromatin detection. Theoretical and Applied Genetics 118: 1295-1307.

Seijo JG, Lavia GI, Fernández A, Krapovickas A, Ducasse D and Moscone EA (2004) Physical mapping of 5S and 18S-25S rRNA genes evidences that Arachis duranensis and A. ipaënsis are the wild diploid species involved in the origin of A. bypogaea (Leguminosae). American Journal of Botany 91: 1294-1303.

Seijo JG, Lavia GI, Fernández A, Krapovickas A, Ducasse D, Bertioli DJ and Moscone EA (2007) Genomic relationships between the cultivated peanut (Arachis hypogaea - Leguminosae) and its close relatives revealed by double GISH. American Journal of Botany 94: 1963-1971.

Simpson CE (1993) Registration of 'TxAG-6' and 'TxAG-7' peanut germplasm. Crop Science 33: 1418.

Simpson CE and Faries MJ (2001) Advances in the characterization of diversity in section Arachis: archeological evidence, crossing results and their relationship in understanding the origin of Arachis hypogaea L. In: III SIRGEALC Simposio de recursos genéticos para a America Latina e Caribe. Londrinas: Instituto Agronómico do Paraná, pp. 103-104.

Simpson CE, Starr JL, Church GT, Burow MD and Paterson AH (2003) Registration of 'NemaTAM' Peanut. Crop Science 43: 1561.

Simpson CE, Starr JL, Nelson SC, Woodard KE and Smith OD (1993) Registration of TxAG6 and TxAG7 peanut germplasm. Crop Science 33: 1418.

Singh AK and Moss JP (1982) Utilization of wild relatives in genetic improvement of Arachis hypogaea L. 2. Chromosome complements of species in the section Arachis. Theoretical and Applied Genetics 61: 305-314.

Smartt J (1990) The groundnut, Arachis hypogaea L. In: Smartt J (ed.) Grain Legumes: Evolution and Genetic Resources. Cambridge: Cambridge University Press, pp. 30-84.

Smartt J and Stalker HT (1982) Speciation and cytogenetics in Arachis. In: Pattee HE and Young CT (eds) Peanut Science and Technology. Yoakum, TX: American Peanut Research and Education Society, pp. 21-49.

Smartt J, Gregory WC and Gregory MP (1978) The genomes of Arachis bypogaea. 1. Cytogenetic studies of putative genome donors. Euphytica 27: 665-675.

Smith BW (1950) Arachis hypogaea. Aerial flower and subterranean fruit. American Journal of Botany 37: $802-815$.
Stalker HT (1991) A new species in section Arachis of peanuts with a D genome. American Journal of Botany 78: 630-637.

Stalker HT and Beute MK (1993) Registration of four inter specific peanut germplasm lines resistant to Cercospora arachidicola. Crop Science 33: 1117.

Stalker HT, Wynne JC and Company M (1979) Variation in progenies of an Arachis hypogaea $\times$ diploid wild species hybrid. Euphytica 28: 675-684.

Subramanian V, Gurtu S and Nigam SN (2000) Identification of DNA polymorphism in cultivated groundnut using random amplified polymorphic DNA (RAPD) assay. Genome 43: 656-660.

Tallury SP, Hilu KW, Milla SR, Friend SA, Alsaghir M, Stalker HT and Quandt D (2005) Genomic affinities in Arachis section Arachis (Fabaceae): molecular and cytogenetic evidence. Theoretical and Applied Genetics 111: 1229-1237.

Tang R, Gao G, He L, Han Z, Shan S, Zhong R, Zhou C, Jiang J, Li Y and Zhuang W (2007) Genetic diversity in cultivated groundnut based on SSR markers. Journal of Genetics and Genomics 34: 449-459.

Tang R, Zhuang W, Gao G, He L, Han Z, Shan S, Jiang J and Li Y (2008) Phylogenetic relationships in genus Arachis based on SSR and AFLP markers. Agricultural Sciences in China 7: 405-414.

Valls JFM and Simpson CE (2005) New species of Arachis from Brazil, Paraguay, and Bolivia. Bonplandia 14: 35-64.

Varshney RK, Bertioli DJ, Moretzsohn MC, Vadez V, Krishnamurthy L, Aruna R, Nigam SN, Moss BJ, Seetha K, Ravi K, He G, Knapp SJ and Hoisington DA (2009a) The first SSR-based genetic linkage map for cultivated groundnut (Arachis hypogaea L.). Theoretical and Applied Biology 118. DOI: 10.1007/s00122-008-0933-x

Varshney RK, Close TJ, Singh NK, Hoisington DA and Cook DR (2009b) Orphan legume crops enter the genomics era! Current Opinion in Plant Biology 12: 1-9.

Varshney RK, Mahendar T, Aruna R, Nigam SN, Neelima K, Vadez V and Hoisington DA (2009c) High level of natural variation in a groundnut (Arachis hypogaea L.) germplasm collection assayed by selected informative SSR markers. Plant Breeding 128: 486-494.

Wang CT, Yang XD, Chen DX, Yu SL, Liu GZ, Tang YY and Xu JZ (2007) Isolation of simple sequence repeats from groundnut. Electronic Journal of Biotechnology 10: 473-480.

Wang CT, Wang XZ, Tang YY, Chen DX, Cui FG, Zhang JC and Yu SL (2010) Phylogeny of Arachis based on internal transcribed spacer sequences. Genetic Resources and Crop Evolution DOI: 10.1007/s10722-010-9576-2 (online first).

Williams DE (1996) Aboriginal farming system provides clues to groundnut evolution. In: Pickersgill and Lock JM (eds) Advances in Legume Systematics 8. Legumes of Economic Importance. Kew: Royal Botanic Gardens, pp. 11-17.

Wojciechowski MF, Lavin M and Sanderson MJ (2004) A phylogeny of legumes (Leguminosae) based on analysis of the plastid MatK gene resolves many well-supported subclades within the family. American Journal of Botany 91: 1846-1862. 